\title{
A study on the enzymatic properties and reuse of cellulase immobilized with carbon nanotubes and sodium alginate
}

\author{
Li-Juan Li ${ }^{i^{*}} \mathbb{D}$, Wen-Jing Xia ${ }^{2}$, Gui-Ping Ma' ${ }^{1}$ Yue-Lin Chen ${ }^{1}$ and Yue-Yu Ma'
}

\begin{abstract}
Cellulase has many potential applications in ethanol production, extraction of medicinal ingredients, food, brewing, oil exploration, environmental protection. However, the widespread use of cellulase is limited by its relatively high production costs and low biological activity. Therefore, we studied the enzymatic properties and reusability of cellulase immobilized on multiwalled carbon nanotubes and sodium alginate for the first time. The results showed that the optimum temperature and $\mathrm{pH}$ of immobilized cellulase was $40^{\circ} \mathrm{C}$ and 3.0, respectively. After 1 month of storage at $4{ }^{\circ} \mathrm{C}$, the enzyme activity of immobilized cellulase dropped to $71.2 \%$ of the baseline. Immobilized cellulase was proved to be reusable and maintained $\sim 70 \%$ of its activity after 7 cycles of repeated use. Versus free cellulase, the immobilized cellulase showed good thermal stability, pH resistance, storage stability and reusability, which could be beneficial in large-scale industrial manufacturing processes.
\end{abstract}

\section{Introduction}

Agricultural countries, such as China, have many straw crops, most of which are accumulated or incinerated in the soil. These crop wastes are leading to pollution and a waste of resources. One alternative solution is converting the straw into gas or liquid fuel to produce energy and minimize pollution concurrently ( $\mathrm{Li}$ et al. 2009; Duarte et al. 2013). However, it is currently limited by high production costs, low enzymatic activity and high consumption of cellulase. Immobilized enzymes were allowed the enzyme to be reused in multiple cycles to lower the production costs and overcome such technical bottlenecks (Zhang et al. 2005; Wu and Ma 2008; Tao et al. 2006). Researchers typically immobilize cellulase via covalent crosslinking and physical adsorption (Karimi et al. 2014; Matsuura et al. 2006). Carrier materials chosen to immobilize cellulase were nanoscale materials (Bohara et al. 2016), natural polymers (Andriani et al. 2015), mesoporous materials (Zhang et al. 2016a, b) and magnetic materials (Han et al. 2018); however, high

\footnotetext{
*Correspondence: lilij2002@126.com

1 Department of Medical Examination, Wulanchabu Medical College,

Wulanchabu 012000, Inner Mongolia, China

Full list of author information is available at the end of the article
}

leakage rates were discovered in all these single carrier immobilized enzymes. The leakage rates can be reduced via the introduction of functional groups, but the process is complex and the costs of biocatalysis can also be increased (Pang et al. 2015). Two interesting carrier groups that will be highlighted in this work are carbon nanotubes and sodium alginate.

Since their discovery in 1991, carbon nanotubes have attracted much attention due to their unique structure (Huang and Tsai 2009). They are composed of graphite flakes in cylindrical structure. Single-walled carbon nanotubes (SWCNTs) consist of only one sheet of graphite flake curling around a central axis, while multi-walled carbon nanotubes (MWCNTs) are formed by several graphite sheets curling around a central axis (Zhang et al. 2013; Feng and Ji 2011). MWCNTs have better physical and chemical stability, lower price, easier preparation and lower toxicity than SWCNTs (Rastian et al. 2014; Lee et al. 2006). Carbon nanotube immobilized enzymes have a large surface area, high enzyme content, and superior dispersibility (Apetrei and Apetrei 2015; Pang et al. 2015). In addition, the dimensions of the carbon nanotubes are similar to those of the enzyme, which facilitates an efficient reaction (Janegitz et al. 2011). Finally, they are easy 
to be separated from the reaction system, along with some other features as reusable, feasible in transportation and storage, stable and economical. These characteristics can potentially increase their commercialization (Mohamad et al. 2015; Ansari and Husain 2012; Wan et al. 2015).

Besides its non-toxicity and low price, Sodium alginate has many practical applications (Guzik et al. 2014). It is a natural polysaccharide formed by the glycosidic bond between $\beta$-D-mannuronic acid and $\alpha$-L-guluronic acid, and it can be extracted from marine plants such as sea vegetables and giant kelp (Abd EI-Ghaffar and Hashem 2013). $\mathrm{Ca}^{2+}$ can interact with carboxyl groups to form microspheres with the existence of guluronic acid alginate, demonstrating excellent mechanical strength and flexibility (Ozyilmaz and Gezer 2010; Cheirsilp et al. 2009). That is one of the reasons why it is commonly used as a carrier material for immobilized enzymes.

In this study, cellulase has been immobilized with carriers MWCNTs and sodium alginate. This process can minimize the side effects caused by high leakage rates of single carrier immobilized enzymes. These two carriers are easy to obtain and economical, with an extra benefit of lower costs in biocatalysis. In addition, temperature, $\mathrm{pH}$, stability, reusability and other enzymatic properties of the system were studied to provide a basis for the potential industrial application of immobilized enzymes.

\section{Materials and methods \\ Materials}

Trichoderma cellulase $(10 \mathrm{U} / \mathrm{mg})$ (Shanghai Ryon Biological Technology Co., Ltd., Shanghai, China); MWCNTs with an outer diameter of 15-30 nm and a length of $1.5 \mu \mathrm{m}$ (Shenzhen Nanotech Port Co., Ltd., Shenzhen, China); Corn stalks (from Chahar Right Banner Wulanchabu, Inner Mongolia).

\section{Immobilization of cellulase by MWCNTs and sodium alginate}

Cellulase $(75 \mathrm{mg})$ was added to $25 \mathrm{~mL}$ of $50 \mathrm{mmol} / \mathrm{L} \mathrm{pH}$ 5.0 citrate- $\mathrm{Na}_{2} \mathrm{HPO}_{4}$ buffer, followed by $20 \mathrm{mg}$ of MWCNTs. The solution was shaken in a $40{ }^{\circ} \mathrm{C}$ water bath at $200 \mathrm{rpm}$ for $3 \mathrm{~h}$ (Zhou et al. 2014). Next, $100 \mathrm{~mL}$ of $3.5 \%$ sodium alginate was added, respectively with continuous mixing. The mixture was drawn into a $5 \mathrm{~mL}$ syringe to a height of $20 \mathrm{~cm}$, and $2 \% \mathrm{CaCl}_{2}$ solution was injected in immediately to form smooth globules. Subsequently, the globules were filtered and the $\mathrm{CaCl}_{2}$ solution was replaced to static hardening in a $4{ }^{\circ} \mathrm{C}$ refrigerator for $2 \mathrm{~h}$. The globules were filtered out again and the water surface was blotted after another wash step. Finally, the immobilized cellulase was obtained and stored at $4{ }^{\circ} \mathrm{C}$ (Zhao et al. 2007).

\section{Determination of cellulase activity}

Carboxymethyl cellulase (CMC) was used as a substrate and was determined by the 3,5-dinitrosalicylic acid (DNS) method (Zhou 2008). First, $1.0 \mathrm{~mL}$ of $50 \mathrm{mmol} / \mathrm{L}$ citrate$\mathrm{Na}_{2} \mathrm{HPO}_{4}$ buffer ( $\mathrm{pH} 4.8$ ) and $0.5 \mathrm{~mL}$ of $1 \% \mathrm{CMC}$ were added into a $25 \mathrm{~mL}$ graduated test tube. Then, $0.5 \mathrm{~mL}$ of enzyme solution was added and the tube was put in a $50{ }^{\circ} \mathrm{C}$ water bath for $30 \mathrm{~min} .3 \mathrm{~mL}$ DNS was added afterward and put in boiling water bath for $5 \mathrm{~min}$. Subsequent to cooling process, distilled water was added to maintain a constant volume of $25 \mathrm{~mL}$. The absorbance of the 3-amino5-nitrosalicylic acid was detected via colorimetric method at $540 \mathrm{~nm}(0.5 \mathrm{~mL}$ distilled water was used to replace the enzyme solution as blank control). The reducing sugar produced by the hydrolysis of cellulase can reduce DNS to 3-amino-5-nitrosalicylic acid, thus the product is red under alkaline condition and has a maximum absorbance at $540 \mathrm{~nm}$. The optical density is proportional to the reducing sugar content within the linear dynamic range. The reducing sugar content was calculated via a standard glucose curve equation, and the cellulase activity was calculated by the following formula. The immobilized cellulase activity was determined by replacing $0.5 \mathrm{~mL}$ of enzyme solution with $0.5 \mathrm{~mL}$ distilled water and immobilized enzyme, the other steps remained the same as the determination of free cellulase activity. Three independent experiments have been performed to obtain the data. The cellulase activity was calculated as:

$$
\begin{aligned}
& \text { Free cellulase activity }(\mathrm{U} / \mathrm{L}) \\
& \qquad=\frac{\text { reducing sugar content }(\mathrm{mg}) \times \mathrm{N} \times 1000}{0.18 \times \mathrm{t} \times \mathrm{V}} \\
& \text { Immobilized cellulase activity }(\mathrm{U} / \mathrm{g}) \\
& =\frac{\text { reducing sugar content }(\mathrm{mg}) \times 1000}{0.18 \times \mathrm{t} \times \mathrm{g}}
\end{aligned}
$$

Note: t: reaction time of enzyme and substrate, V: volume of added cellulase solution during the determination of enzyme activity, $\mathrm{N}$ : dilution ratio, 0.18: $1 \mu \mathrm{mol}$ glucose is equivalent to $0.18 \mathrm{mg}$ glucose, g: the amount of added immobilized cellulase.

\section{Determination of enzyme immobilization yield}

The total activity of the free cellulase added during the immobilization process, $\mathrm{M}_{0}$, and the activity of cellulase in the supernatant after immobilization, $M_{1}$, were detected. Three independent experiments have been performed to obtain the data. The immobilization yield was calculated as:

$$
\left(\mathrm{M}_{0}-\mathrm{M}_{1}\right) / \mathrm{M}_{0} \times 100 \%
$$




\section{Effect of sodium alginate concentration on cellulase immobilization yield}

The cellulase immobilization yield were measured by altering different sodium alginate solutions in the concentration of $2 \%, 2.5 \%, 3 \%, 3.5 \%$ or $4 \%$.

\section{Effect of enzyme concentration on immobilized cellulase activity and immobilization yield}

The immobilized cellulase activity and immobilization yield were measured by altering enzyme solution with different concentration as $1 \mathrm{mg} / \mathrm{mL}, 2 \mathrm{mg} / \mathrm{mL}, 3 \mathrm{mg} / \mathrm{mL}$, $4 \mathrm{mg} / \mathrm{mL}, 5 \mathrm{mg} / \mathrm{mL}, 6 \mathrm{mg} / \mathrm{mL}$.

\section{Effect of temperature on cellulase activity}

The cellulase activity on immobilized and free enzymes were measured by altering water bath temperatures as $30{ }^{\circ} \mathrm{C}, 40{ }^{\circ} \mathrm{C}, 50{ }^{\circ} \mathrm{C}, 60{ }^{\circ} \mathrm{C}$ and $70{ }^{\circ} \mathrm{C}$, respectively. The graph was drawn with time being the abscissa and relative cellulase activity and immobilized cellulase activity being the ordinate.

\section{Effect of $\mathrm{pH}$ on cellulase activity}

The activity of immobilized and free cellulases were measured at $50 \mathrm{mmol} / \mathrm{L}$ with citrate- $\mathrm{Na}_{2} \mathrm{HPO}_{4}$ buffer of different $\mathrm{pH}$ as 3.0, 4.0, 5.0, 6.0 and 7.0 in a $50{ }^{\circ} \mathrm{C}$ water bath. The graph was drawn with $\mathrm{pH}$ being the abscissa and relative cellulase activity and immobilized cellulase activity being the ordinate.

\section{PH stability of cellulase}

The immobilized and free cellulases were added to $50 \mathrm{mmol} / \mathrm{L}$ citrate- $\mathrm{Na}_{2} \mathrm{HPO}_{4}$ buffer of different $\mathrm{pH}$ as 3.0, 4.0, 5.0, 6.0 and 7.0 in a $40{ }^{\circ} \mathrm{C}$ water bath for $1 \mathrm{~h}$. The cellulase activity was then measured. The initial cellulase activity was $100 \%$, and the trend of cellulase activity changing over time was showed with $\mathrm{pH}$ being the abscissa and relative activity and immobilized cellulase activity being the ordinate.

\section{Storage stability of cellulase}

The immobilized and free cellulases were stored in a $4{ }^{\circ} \mathrm{C}$ refrigerator for 1 month. The cellulase activity over time was determined with the initial cellulase activity set as $100 \%$.

\section{Reusable hydrolysis CMC by immobilized cellulase}

Immobilized cellulase $(0.2 \mathrm{~g})$ was added to a $25 \mathrm{~mL}$ graduated test tube, together with $0.5 \mathrm{~mL}$ CMC (1\%) and $1.5 \mathrm{~mL}$ citrate- $\mathrm{NaH}_{2} \mathrm{PO}_{4}$ buffer $(50 \mathrm{mmol} / \mathrm{L}, \mathrm{pH} 3.0$ ). After $30 \mathrm{~min}$ reaction in a $40{ }^{\circ} \mathrm{C}$ water bath, the reaction liquid was removed to confirm the cellulase activity. The immobilized cellulase was rinsed thrice with $50 \mathrm{mmol} / \mathrm{L}$ citrate- $\mathrm{NaH}_{2} \mathrm{PO}_{4}$ buffer ( $\mathrm{pH}$ 3.0). Next, fresh 1\% CMC was added and the activity of the immobilized cellulase was measured again. Finally, the reusability of immobilized cellulase was determined after repeated cycles.

\section{Straw pretreatment}

The straw was cut into $2-3 \mathrm{~cm}$ sections and ground into a powder to pass through a 40 mesh screen. $10 \mathrm{~g}$ dry straw powder was then placed in a flask along with $200 \mathrm{~mL}$ of $1 \%$ dilute sulfuric acid and the mixture was left for incubation for $\sim 12 \mathrm{~h}$. Then dilute acid hydrolysis was performed at $121{ }^{\circ} \mathrm{C}$ for $2 \mathrm{~h}$. The residue was filtered, washed with water until neutral, dried, ground into a 40 mesh powder, cooled to room temperature and stored (Yao 2008).

\section{Reusable hydrolysis straw by immobilized cellulase}

$2 \mathrm{~g}$ of immobilized cellulase and $1 \mathrm{~g}$ of straw powder were added into $50 \mathrm{~mL}$ citrate- $\mathrm{Na}_{2} \mathrm{HPO}_{4}$ buffer $(50 \mathrm{mmol} / \mathrm{L}$, $\mathrm{pH}$ 3.0) and then placed in a $40{ }^{\circ} \mathrm{C}$ water bath. After the straw was hydrolyzed for $24 \mathrm{~h}$, the supernatant was removed to measure cellulase activity. The immobilized cellulase was washed thrice with citrate- $\mathrm{Na}_{2} \mathrm{HPO}_{4}$ buffer $(50 \mathrm{mmol} / \mathrm{L}, \mathrm{pH} 3.0)$, and then $1 \mathrm{~g}$ fresh straw powder and $50 \mathrm{~mL}$ citrate- $\mathrm{Na}_{2} \mathrm{HPO}_{4}$ buffer $(50 \mathrm{mmol} / \mathrm{L}, \mathrm{pH} 3.0)$ was added again for hydrolysis. Next, the reusability of the immobilized cellulase was determined after repeated cycles.

\section{Results}

\section{Effect of sodium alginate concentration on cellulase} immobilization yield

Figure 1 shows that the immobilization yield of cellulase increases with increasing sodium alginate concentration. The maximum immobilization yield was $57.2 \%$ when the








Fig. 2 Effects of enzyme concentration on immobilized cellulase activity and immobilization yield

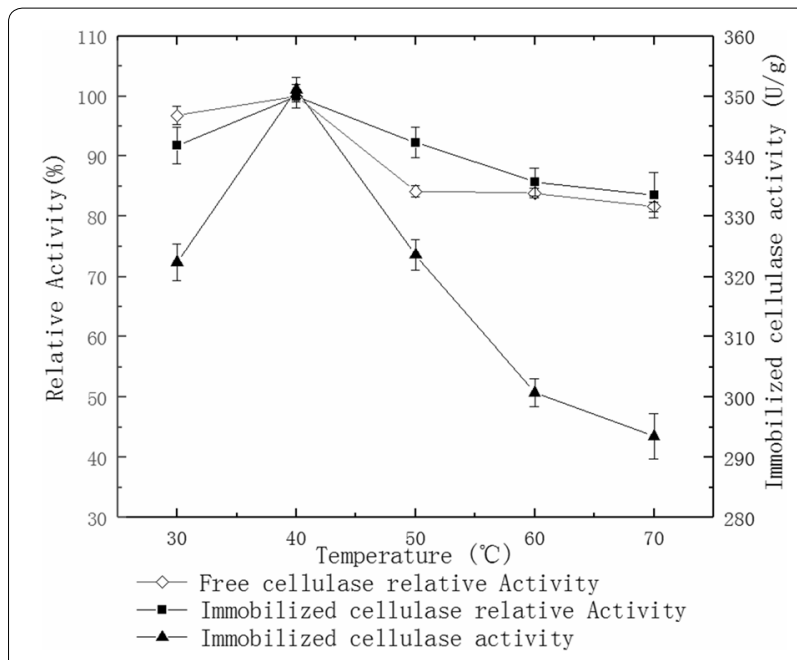

Fig. 3 Effect of temperature on cellulase activity

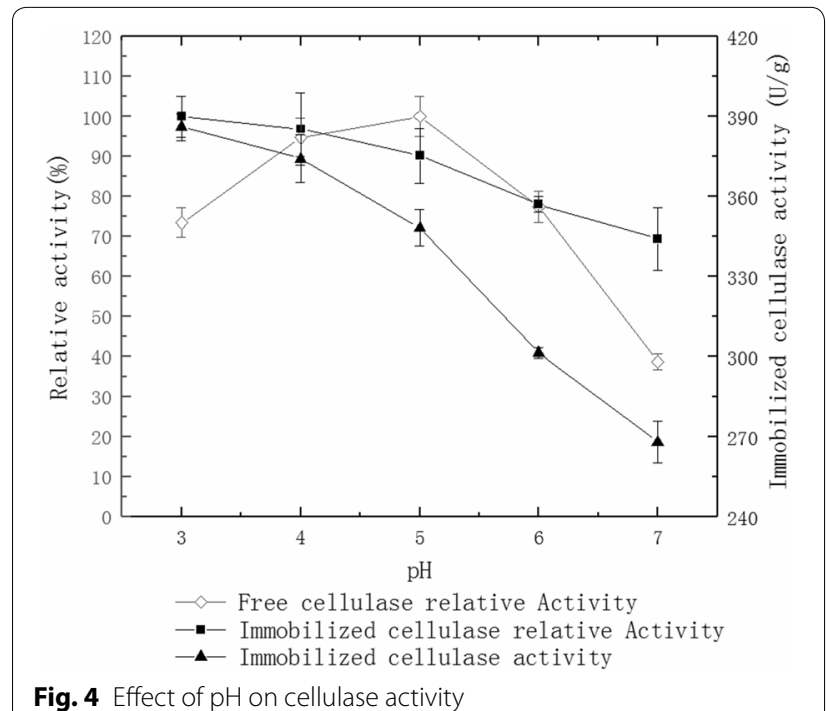

Fig. 4 Effect of $\mathrm{pH}$ on cellulase activity

\section{Cellulase pH stability}

Figure 5 shows that the best $\mathrm{pH}$ for immobilized cellulase and free cellulase to maintain stability is 3.0. Higher $\mathrm{pH}$ decreases the stability of cellulase.

\section{Storage stability of cellulase}

Figure 6 shows that the enzyme activity remains at $88.1 \%$ of the initial immobilized cellulase activity after it is stored for 7 days; the free cellulase activity decreases to $72.7 \%$ of the initial cellulase activity. After storage of the immobilized cellulase for 30 days, the enzyme activity remains at $71.2 \%$ of the initial immobilized cellulase activity, but the free cellulase activity decreases to $56.8 \%$. 




Fig. 5 Cellulase $\mathrm{pH}$ stability

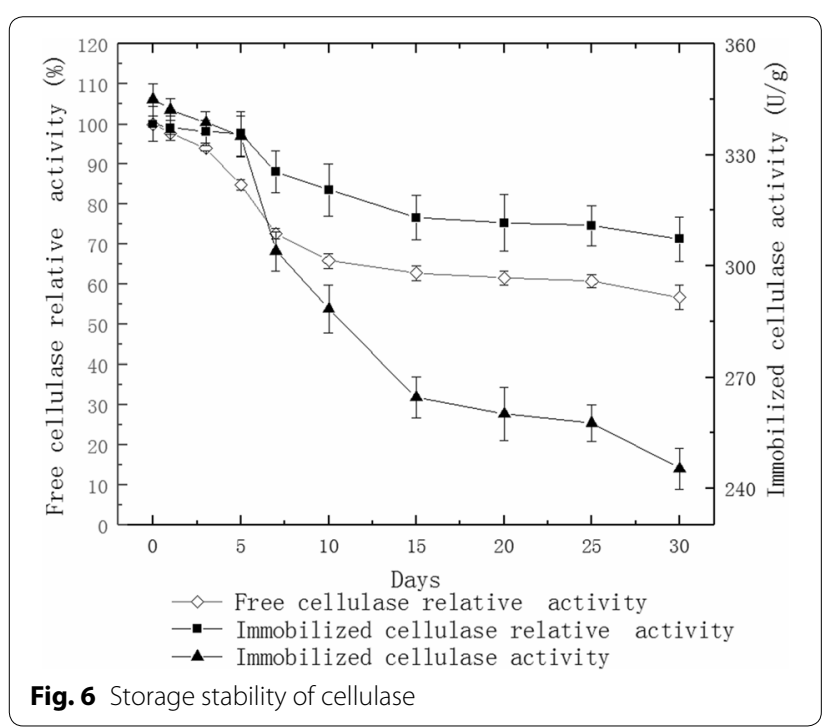

\section{Reusable hydrolysis CMC by the immobilized cellulase}

Figure 7 shows that the immobilized cellulase activity is only $59.5 \%$ of the initial immobilized cellulase activity when directly immobilized with MWCNTs and after three reused cycles. The immobilized cellulase activity is only $60.9 \%$ of the initial immobilized cellulase activity when directly immobilized with sodium alginate and after three reused cycles. The immobilized cellulase activity remains at $91.2 \%$ of the initial immobilized cellulase activity when immobilized with MWCNTs and sodium alginate and after three reused cycles. The immobilized cellulase activity remains at $71.5 \%$ of baseline after seven reused cycles (Fig. 8) with MWCNTs and sodium alginate.

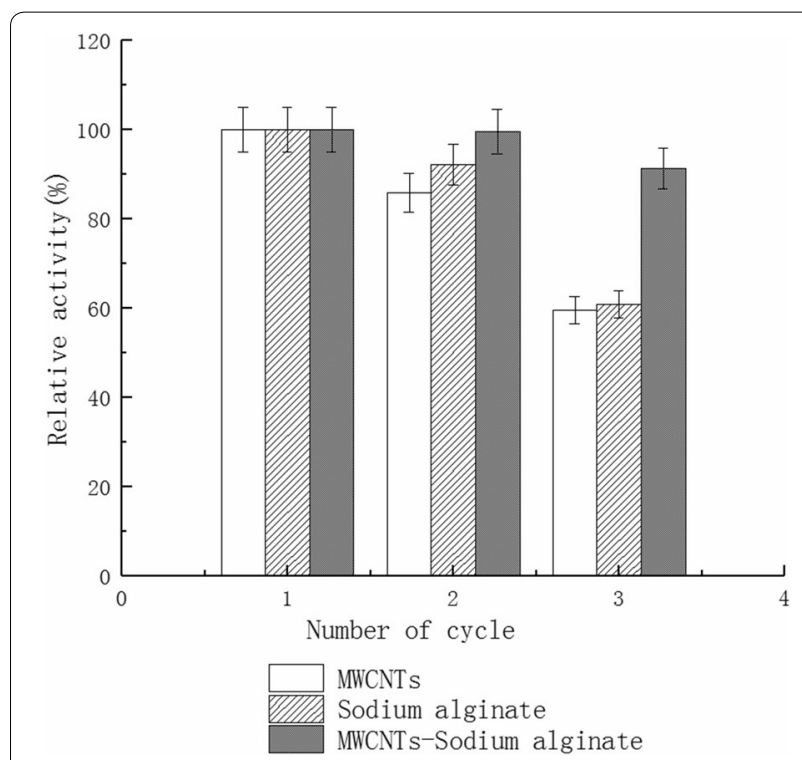

Fig. 7 Reusable hydrolysis CMC by the immobilized cellulase of different materials



Fig. 8 Reusable hydrolysis CMC by the immobilized cellulase

\section{Reusable hydrolysis straw by immobilized cellulase}

Figure 9 shows that the immobilized cellulase activity remains at $67.9 \%$ of the initial immobilized cellulase activity after seven repeated straw hydrolysis cycles.

\section{Discussion}

Here, we discuss the enzymatic properties of the cellulase immobilized by MWCNTs and sodium alginate. We've studied the material's ability to hydrolyze straw in a reusable way and compared immobilized cellulase with free cellulase. 


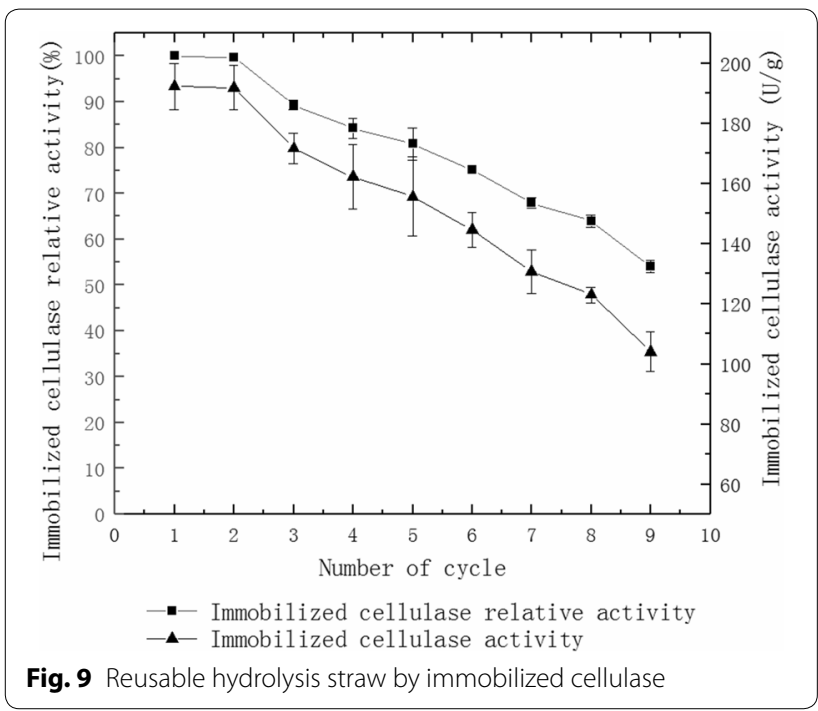

The concentration of sodium alginate affects the enzyme immobilization yield, the mechanical strength of the beads and the difficulty of pelleting. When the concentration of sodium alginate is $1 \%$ and $1.5 \%$, the beads strength is low with an obvious tail phenomenon. When the concentration of sodium alginate is $3.5 \%$, the beads are smooth and round with moderate mechanical strength. Beads are difficult to form at the concentration of $4 \%$ because of the high viscosity of the solution, it is difficult to push the syringe.

The activity of immobilized cellulase gradually increases with increasing enzyme concentration (Fig. 2). The increased activity of the immobilized cellulase is due to the large number of pores on the surface of the MWCNTs. These pores could absorb cellulase; the sodium alginate could perform similarly.

The temperature has a dual effect on enzyme activity: The enzyme activity inhibits at low temperature. The enzyme activity denatures at high temperature and their activity decreases. The optimal temperature for immobilized cellulase and free cellulase is of $40{ }^{\circ} \mathrm{C}$. The immobilized cellulase has better thermal tolerance than free cellulase (Fig. 3) because the carbon nanotubes and sodium alginate offer a rigid external backbone for cellulase molecules. Similarly to previous studies, the effect of high temperature on the active center of the enzyme becomes less prominent (Zhang et al. 2016a, b).

In addition, cellulase has a higher activity within $\mathrm{pH}$ 3.0 to 5.0 . The enzyme activity decreases under alkaline conditions (Fig. 4) because the ionic groups on the surface of cellulase have electrostatic repulsion. This leads to changes in the cellulase activity center and will reduce the overall enzyme activity. However, the activity of immobilized cellulase decreases in a slower speed than that of free cellulase, suggesting a better $\mathrm{pH}$ tolerance in enzyme immobilization. These conclusions are similar to previous studies (Liu et al. 2013; Mubarak et al. 2014; Kim et al. 2017). PH of 3.0 offers the best stability for immobilized and free cellulase (Fig. 5). The stability of the cellulase gradually decreases with increasing $\mathrm{pH}$. However, the rate of decrease is lower with immobilized cellulase because cellulase could be packed into the pores of the MWCNTs and embedded in the calcium alginate microspheres. Therefore, the immobilized cellulase has higher $\mathrm{pH}$ stability than free cellulase, which is confirmed by other studies (Boncel et al. 2013).

The cellulase activity, respectively remains at $71.2 \%$ and $56.8 \%$ of the initial cellulase activity after 30 -day-storage of the immobilized cellulase and free cellulase (Fig. 6). This indicates that the storage stability of cellulase is significantly improved after immobilization, regarded as a vital prerequisite for industrial applications. Thus, immobilized cellulase can be used for large-scale and industrial processes.

The most obvious advantage of immobilized enzymes over free enzyme is that it can be reused (Cheng 2015). In this study, cellulase is immobilized directly by MWCNTs or sodium alginate, but the leakage rate of the cellulase is high (Fig. 7). The leakage rate of the cellulase is reduced due to the adsorption of MWCNTs and the embedded calcium alginate beads. After 7 cycles of repeated hydrolysis of CMC and the straw, the activity of immobilized cellulase still remains at $71.5 \%$ and $67.9 \%$, respectively (Figs. 8 and 9).Good reusability can reduce the amount of free cellulase in industrial production and result in lower production costs. The activity of the immobilized enzyme declines gradually with increasing reuse cycles. This may be because of the relatively weak binding forces via non covalent bonds. Some enzyme molecules cannot be effectively absorbed onto MWCNTs (Hasegawa et al. 2016). The decreased activity may also be due to the hydrophilic characteristics of sodium alginate. The size of the pores gradually becomes larger after repeated use, resulting in increased leakage of the enzyme and reduced activity (Verma et al. 2013).

\section{Abbreviations}

CMC: carboxymethyl cellulase; SWCNTs: single-walled carbon nanotubes; MWCNTs: multi-walled carbon nanotubes; DNS: dinitrosalicylic acid.

\section{Acknowledgements \\ The author are grateful to the Education Department of Inner Mongolia Autonomous Region for the financial support provided for this work.}

\section{Authors' contributions}

LLJ and XWJ designed the study. LLJ and MGP contributed to experiments. $L L J, C Y L$, and MYY contributed to data analysis. LLJ wrote the manuscript. All authors read and approved the final manuscript. 


\section{Funding}

This work was financially supported by the scientific research project of the Inner Mongolia Autonomous Region Education Department Higher Education Institutions of China (No. NJZY17574).

\section{Availability of data and materials}

All obtained data have been included into the manuscript.

\section{Ethics approval and consent to participate}

Not applicable.

\section{Consent for publication}

Not applicable.

\section{Competing interests}

The authors declare that they have no competing interests.

\section{Author details}

${ }^{1}$ Department of Medical Examination, Wulanchabu Medical College, Wulanchabu 012000, Inner Mongolia, China. ${ }^{2}$ Department of Biological Engineering, Nanjing Normal University Taizhou College, Taizhou 225300, JiangSu, China.

Received: 12 April 2019 Accepted: 6 July 2019

Published online: 22 July 2019

\section{References}

Abd El-Ghaffar MA, Hashem MS (2013) Calcium alginate beads encapsulated PMMA-g-CS nano-particles for- chymotrypsin immobilization. Carbohydr Polym 92:2095-2102. https://doi.org/10.1016/j.carbpol.2012.11.084

Andriani D, Sunwoo C, Ryu W, Palmer J, Prasetya B, Park DH (2015) Immobilization of cellulase from newly isolated strain Bacillus subtilis TD6 using calcium alginate as a support material. Bioprocess Biosyst Eng 31(1-2):29-33. https://doi.org/10.1007/s00449-011-0630-z

Ansari SA, Husain Q (2012) Potential applications of enzymes immobilized on/in nano materials: A review. Biotechnol Adv 30:512-523. https://doi. org/10.1016/j.biotechadv.2011.09.005

Apetrei IM, Apetrei C (2015) The biocomposite screen-printed biosensor based on immobilization of tyrosinase onto the carboxyl functionalised carbon nanotube for assaying tyramine in fish products. J Food Eng 149:1-8. https://doi.org/10.1016/j.jfoodeng.2014.09.036

Bohara RA, Thorat ND, Pawar SH (2016) Immobilization of cellulase on functionalized cobalt ferrite nanoparticles. Korean J Chem Eng 33(1):216-222. https://doi.org/10.1007/s11814-015-0120-0

Boncel S, Zniszczol A, Szymanska K, Mrowiec-Bialon J, Jarzebski A, Walczak KZ (2013) Alkaline lipase from Pseudomonas fluorescens non-covalently immobilised on pristine versus oxidised multi-wall carbon nanotubes as efficient and recyclable catalytic systems in the synthesis of Solketal esters. Enzyme Microb Technol 53:263-270. https://doi.org/10.1016/j. enzmictec.2013.05.003

Cheng L (2015) Horseradish peroxidase immobilized on multi-walled carbon nanotubes/cordierite composite carrier and diesel sewage treatment. J B Univ Chem Technol 30:15-34

Cheirsilp B, Jeamjounkhaw P, Aran H (2009) Optimizing an alginate immobilized lipase for monoacylglycerol production by the glycerolysis reaction. J Mol Catal B Enzym 59:206-211. https://doi.org/10.1016/j.molca tb.2009.03.001

Duarte JC, Rodrigues JAR, Moran PJS, Valença GP, Nunhez JR (2013) Effect of immobilized cells in calcium alginate beads in alcoholic fermentation. AMB Express 3:31. https://doi.org/10.1186/2191-0855-3-31

Feng W, Ji PJ (2011) Enzymes immobilized on carbon nanotubes. Biotechnol Adv 29:889-895. https://doi.org/10.1016/j.biotechadv.2010.02.007

Guzik U, Hupert-Kocurek K, Marchlewicz A, Wojciezynska D (2014) Enhancement of biodegradation potential of catechol 1,2-dioxygenase through its immobilization in calcium alginate gel. Electron J Biotechnol 17:83-88. https://doi.org/10.1016/j.ejbt.2014.02.001

Han J, Rong JH, Wang Y (2018) Immobilization of cellulase on thermosensitive magnetic microspheres: improved stability and reproducibility. Bioprocess Biosyst Eng 41(7):1051-1060. https://doi.org/10.1007/s0044 9-018-1934-z
Hasegawa F, Inoue H, Yano S, Yokoyama S, Imou K (2016) Evaluation of cellulase activity in enzymatic hydrolysis residues for efficient enzyme reuse. J Jpn Inst Energy 95(10):930-936. https://doi.org/10.3775/jie.95.930

Huang JL, Tsai YC (2009) Direct electrochemistry and biosensing of hydrogen peroxide of horseradish peroxidase immobilized at multiwalled carbon nanotube/alumina-coated silica nanocomposite modified glassy carbon electrode. Sensor Actuat B 140:267-272. https://doi.org/10.1016/j. snb.2009.04.033

Janegitz BC, Pauliukaite R, Ghica ME, Brett CAM, Fatibello-Filho O (2011) Direct electron transfer of glucose oxidase at glassy carbon electrode modified with functionalized carbon nanotubes within a dihexadecyl phosphate film. Sensor Actuat B 158:411-417. https://doi.org/10.1016/j. snb.2011.06.048

Karimi M, Chaudhury I, Cheng J, Safari M, Sadeghi R (2014) Immobilization of endo-inulinase on non-porous amino functionalized silica nanoparticles. J Mol Catal B Enzym 104:48-55. https://doi.org/10.1016/j.molca tb.2014.01.025

Kim YS, Lee CJ, Ma JY (2017) Enhancement of active compound, genipin, from Gardeniae Fructus using immobilized glycosyl hydrolase family 3ß-glucosidase from Lactobacillus antri. AMB Express 7:64. https://doi. org/10.1186/s13568-017-0360-y

Lee YM, Kwon O, Yoon YJ (2006) Immobilization of horseradish peroxidase on multi-wall carbon nanotubes and its electrochemical properties. Biotechnol Lett 28:39-43. https://doi.org/10.1007/s10529-005-9685-8

Li HY, Zhang ZQ, Li RH (2009) Study on cellulase enzymatic hydrolysis of microwave-acid pretreated corn stalk. J North A\&F Univ 37(12):181-187. https://doi.org/10.13207/j.cnki.jnwafu.2009.12.013

Liu XH, Bu CH, Nan ZH (2013) Enzymes immobilized on amine-terminated ionic liquid-functionalized carbon nanotube for hydrogen peroxide determination. Talanta 105:63-68. https://doi.org/10.1016/j.talan ta.2012.11.059

Matsuura K, Saito T, Okazaki T, Ohshima S, Yumura M, lijima S (2006) Selectivity of water soluble proteins in single-walled carbon nanotube dispersions. Chem Phys Lett 429(4-6):497-502. https://doi.org/10.1016/j.cplet t.2006.08.044

Mohamad NR, Buang NA, Mahat NA, Lok YY, Huyop F, Aboul NA, Wahab RA (2015) A facile enzymatic synthesis of geranyl propionate by physically adsorbed Candida rugosa lipase onto multi-walled carbon nanotubes. Enzyme Microb Technol 72:49-55. https://doi.org/10.1016/j.enzmi ctec.2015.02.007

Mubarak NM, Wong JR, Tan KW, Sahu JN, Abdullah EC, Jayakumar NS, Canesan P (2014) Immobilization of cellulase enzyme on functionalized multiwall carbon nanotubes. J Mol Catal B Enzym 107:124-131. https://doi. org/10.1016/j.molcatb.2014.06.002

Ozyilmaz G, Gezer E (2010) Production of aroma esters by immobilized Candida rugosa and porcine pancreatic lipase into calcium alginate gel. J Mol Catal B Enzym 64:140-145. https://doi.org/10.1016/j.molcatb.2009.04.013

Pang R, Li MZ, Zhang CD (2015) Degradation of phenolic compounds by laccase immobilized on carbon nanomaterials: diffusional limitation investigation. Talanta 113:38-45. https://doi.org/10.1016/j.talanta.2014.07.045

Rastian Z, Khodadadi AA, Vahabzadeh F, Bortolini C, Dong MD, Mortazavi Y, Mogharer A, Naseh MV, Guo Z (2014) Facile surface functionalization of multiwalled carbon nanotubes by soft dielectric barrier discharge plasma: Generate compatible interface for lipase immobilization. Biochem Eng J 90:16-26. https://doi.org/10.1016/j.bej.2014.05.009

Tao R, Bai XF, Jiang L (2006) New energy of sustainable development in future: production of alcohol fermented by stover. Liquor Mak 33(3):45-48. https ://doi.org/10.3969/j.issn.1002-8110.2006.03.020

Verma ML, Naebe M, Barrow CJ, Puri M (2013) Enzyme immobilisation on amino-functionalised multi-walled carbon nanotubes: structural and biocatalytic characterisation. Plos ONE 10:1371-1382. https://doi. org/10.1371/journal.pone.0073642

Wan XM, Zhang C, Yu DH (2015) Enzyme immobilized on carbon nanotubes. Prog Chem 27(9):1251-1259. https://doi.org/10.7536/PC150212

Wu XQ, Ma CL (2008) Research on ethanol production through corn stalk fermentation. Mod Agric Sci Technol 13:240-243. https://doi.org/10.3969/j. issn.1002-8110.2008.05.008

Yao QL (2008) Selection of Carbon Sources and Optimization of Conditions for Cellulase Production by Trichoderma reesei. J N Univ Fores 38:20-28 
Zhang CD, Luo SM, Chen W (2013) Activity of catalase adsorbed to carbon nanotubes: effects of carbon nanotube surface properties. Talanta 13:142-147. https://doi.org/10.1016/j.talanta.2013.03.027

Zhang DZ, Hegab HE, Lvov Y, Snow D, Palmer J (2016a) Immobilization of cellulase on a silica gel substrate modified using a 3-APTES self-assembled monolayer and James Palmer. Springer Plus 5(1):48-68. https://doi. org/10.1186/s40064-016-1682-y

Zhang Q, Lu J, Hou L (2005) Research progress of alcoholic fermentation of corn stover. Feed Ind 26(9):20-23. https://doi.org/10.3969/j. issn.1001-991X.2005.09.006

Zhang YQ, Wang Z, Tang AX (2016b) Preparation of lipase immobilized on functionalized carbon nanotubes and its synthesis of biodiesel. J Renew Energy 34(9):1411-1416. https://doi.org/10.13941/j.cnki.21-1469/ tk.2016.09.022
Zhao LG, Li LJ, Wang P (2007) Immobilization of $\beta$-glucosidase by sodium alginate. Chin J Bioprocess Eng 5(4):25-31. https://doi.org/10.3969/j. issn. 1672-3678.2007.04.006

Zhou H, Qu YY, Kong CL (2014) Catalytic performance and molecular dynamic simulation of immobilized C-Cbond hydrolase based on carbon nanotube matrix. Colloid Surfaces B 116:365-371. https://doi.org/10.1016/j. colsurfb.2014.01.018

Zhou Z (2008) Enhancement in hydrolysis of corncob by cellulase with the addition xylanases. J N Univ Fores 38:10-26

\section{Publisher's Note}

Springer Nature remains neutral with regard to jurisdictional claims in published maps and institutional affiliations.

\section{Submit your manuscript to a SpringerOpen ${ }^{\circ}$ journal and benefit from:}

- Convenient online submission

- Rigorous peer review

- Open access: articles freely available online

- High visibility within the field

- Retaining the copyright to your article

Submit your next manuscript at $\boldsymbol{\nabla}$ springeropen.com 